\title{
THE RENEGOTIATION OF GOVERNMENT WAR CONTRACTS
}

\author{
CIAY Judson*
}

$\mathrm{I}^{\mathrm{N}}$ N THE spring of $x 942$ there was considerable critical discussion of industrial war profits alleged to be excessive. While our sons were sacrificing their lives for victory, it was said, the manufacturer was making inordinate amounts of money out of the war effort. This led to a hue and cry in Congress, and an attack on the war "profiteer."

A fixed limitation on profits was first proposed, but abandoned, probably at the request of the armed services which were primarily interested in the maintenance of production at a high level and which feared that a fixed limit on profits would interfere with that objective. From the political standpoint, however, something had to be done to correct this real or imagined evil. The excess profits tax law was not enough. The "profiteer" must be further curbed. The only question was, how? The law for the renegotiation of government war contracts, passed as Section 403 of Title IV of the 6th Supplemental National Defense Appropriation Act, I942, and approved April 28, I942, was the answer. ${ }^{\text {I }}$

Summary of the Act.-The original Act referred to contracts with the War and Navy Departments and the Maritime Commission. It provided that the secretary of each department (which included the Chairman of the Maritime Commission) was authorized and directed to insert in any contract in excess of one hundred thousand dollars thereafter entered into by such department, a provision for the renegotiation of the contract price at a time when, in the judgment of the secretary, the profits could be determined with reasonable certainty.

More startling, however, was the provision in subparagraph (c) of the Act authorizing and directing the secretary of each department "whenever in his opinion excessive profits have been realized or are likely to be realized" from any contract with such department (or from any subcontract thereunder) to require the contractor (or subcontractor) to renegotiate the contract price. This meant the recapture of profits already

* Member of the Mllinois Bar; Member of the Price Adjustment Section Board, Chicago Ordnance District. This article was read before the Section on Commercial Law of the Illinois Bar Association. It expresses the personal views of the author only.

${ }_{5} 5$ Stat. 245 (r942), 4 I U.S.C.A. n. preced. § I (Supp. I942), amended by H.R. 7378, 77 th Cong. 2d Sess. Title VIII, §801 (Pub. L. No. 753, Oct. 2I, I942). 
realized under a contract already made and already partly or even fully performed, although there may be no provision whatever in the contract for any renegotiation or recapture.

As is so often the case in modern legislation, an attempt is made to cover one of the fundamental features of the Act by definition. The Act states: 'The term 'renegotiate' and 'renegotiation' include the refixing by the Secretary of the Department of the contract price." There is some difference of opinion as to whether this language means that the secretary, if he cannot agree after renegotiation with the contractor upon the amount of the "excessive profits," may fix the contract price himself without the consent of the contractor. In spite of difficulties in construction, it is hard to believe that the language of the statute is intended to mean anything less than this. It has been suggested, however, that it means nothing more than that after an "excessive profit" has been agreed upon following renegotiation, the secretary has the power then to fix the contract price to accord with this agreement. If this interpretation is to be followed, the language in question would seem to be entirely superfluous.

Those who are administering this Act are making every effort to come to an agreement with each contractor, provided only that the interest of the government and the objectives of the law are not compromised in the process. Up to the present time I know of no arbitrary refixing of the contract price. Every settlement has, so far as I am aware, been based upon an agreement.

Amendments.-On October 21, I942, as a rider to the Revenue Act, amendments to the renegotiation law were adopted and the program was enlarged to include contracts with the Treasury Department. ${ }^{2}$ The amendments were, in the main, helpful and practical.

Of doubtful utility, however, is the inclusion for the first time of a socalled definition of "excessive profits." It reads: "The term "excessive profits' means any amount of a contract or subcontract price which is found as a result of renegotiation to represent excessive profits." If renegotiation includes the right of the secretary to fix the contract price, the definition just quoted from the Act says nothing more than that "excessive profits" means excessive profits as agreed to or as fixed by the secretary. This is not particularly helpful as a guide in the administration of the Act or in the determination of just what profits are excessive. Perhaps the addition of this "definition" was intended not as an aid in administering the Act, but rather to make judicial review less likely by giving a greater degree of finality to the results of renegotiation.

a C.C.H. War L. Serv. ๆ 26,I35 (1942). 
Some of the amendments are of greater significance and utility, although for the most part they merely incorporate into the statute policies which had been announced, and to a limited extent put into practice, by the renegotiating agencies. One of these is that when a contractor has two or more contracts, or subcontracts, the government, in its discretion (the statute says the secretary in his discretion) may renegotiate to eliminate excessive profits on some or all of such contracts, or subcontracts, as a group without separately renegotiating the contract price of each agreement. The practice was being followed prior to October $2 \mathrm{I}$, I942, the date of the amendments, but there was some doubt as to its validity.

The amendments now provide, also, that after renegotiation has determined the amount of the excessive profits, and the determination has been embodied in an agreement, it shall not again be reopened as to the matters agreed upon, and shall not be modified or set aside by any officer of the government, or in any suit or other legal proceeding. Prior to the amendments, contractors had been assured by the government renegotiating officials, but perhaps without statutory authority, that an agreement once made with reference to excessive profits would not thereafter be disturbed. It is extremely helpful, therefore, that any uncertainty on this score has now been removed from the administration of the Act.

The original Act provided that it should remain in force for three years after the termination of the war. The amendments provide that no renegotiation of a contract price pursuant to the Act shall be commenced by the secretary more than one year after the close of the fiscal year of the contractor within which the contract has been completed. If certain forms are filed by the contractor or subcontractor with the department concerned, notice that the contracts covered by the forms are to be renegotiated must be given within one year thereafter, and actual renegotiation must be started within sixty days after the giving of such notice. These two sections place a time limit on the whole renegotiation procedure, which is much more favorable for contractors than the period set forth in the original Act. No longer will they be left in doubt for years whether the funds in their bank accounts really belong to them.

One of the amendments has greatly extended the application of the Act. The original Act had included subcontracts as well as prime contracts. The amendments now define a subcontract as "any purchase order or agreement to perform all or any part of the work, or to make or furnish any article, required for the performance of another contract or subcontract." The term "article" is also very broadly defined.

Another amendment gives to the secretary the power, in contracts here- 
after made, to fix the period which renegotiation shall cover, and, if in his opinion the provisions of the contract are adequate to prevent excessive profits, to agree that renegotiation shall apply only to a portion of the contract, or shall not apply to performance during a specified period or periods, and that the contract price in effect during such period or periods shall not be subject to any further renegotiation. The law thus makes it possible to provide that for limited periods, within which the contractor should be able to estimate its costs with reasonable accuracy, there shall be no renegotiation. One of the great difficulties in the past, and the real reason why renegotiation is needed, is the fact that vast numbers of contracts were long term, requiring the production of enormous quantities of materials which the contractor may never have produced before. This obviously meant that costs had to be estimated in unknown fields. Necessarily, many of these estimates proved to be too high and resulted in profits entirely beyond the original contemplation of the parties. If in the future, acting under the authority granted by the amendments, prices are fixed by contract for a relatively short period of time for which reasonably accurate estimates of costs may be made, the government can agree with the contractor that for that period there will be no subsequent renegotiation. As to such contracts, this will remove all uncertainty from the arrangements beyond that involved in any ordinary business deal and will remove entirely the necessity for renegotiation. For some time, however, the renegotiation program will have to be carried out under the Act because it involves billions of dollars under thousands of contracts already entered into, many of which have already been largely performed.

Exemptions.-The Act, although broad in scope, does have some exemptions and exclusions. No contract on which final payment was made prior to April 28, I942, and no contractor whose total war business, for the fiscal year in question, including subcontracts, does not exceed one hundred thousand dollars, is subject to renegotiation. One of the amendments provides that the Act shall not apply to contracts for the product of a mine, oil or gas well, or other natural deposit, or timber, "which has not been processed, refined, or treated beyond the first form or state suitable for industrial use," whatever that may mean. The secretaries are authorized by joint regulation to interpret this exemption. This had not yet been done as this paper is written.

By the present administrative practice, profits from other government business than that with the four departments specifically mentioned in the 
Act, as, for example, sales of equipment to Defense Plant Corporation, may be renegotiated if the contractor consents.

Commercial business of the contractor must be segregated from its war business, because the Act directs renegotiation of the profits realized on the latter (more properly on business with the War, Navy, and Treasury Departments, and the Maritime Commission), and does not permit renegotiation of profits derived from the former. It is extremely difficult in many cases to draw the line between business which is and business which is not renegotiable. Particularly is this true of many subcontracts. The broad definition of a subcontract which is subject to renegotiation has already been referred to. It is not a simple matter, however, to determine whether an article furnished by a subcontractor is "required" for the performance of a prime contract. The manufacturer of a necessary part of a machine furnished to a prime contractor who uses that machine exclusively in the production of munitions would certainly be covered by the Act. If the article furnished were tile for the floor of a factory engaged in war work, this, too, would doubtless be included. If the article furnished were a bus used to take the workmen in a war plant to and from the factory, should the subcontract for furnishing the bus be included? Would a subcontractor who furnished soap and towels for the workmen's washrooms in a war factory be subject to renegotiation? These hypothetical questions illustrate that type of difficulty which is so often faced in the application of laws, namely, where to draw the line in doubtful cases.

Government by Men.- In this law Congress has taken a long step away from that hallowed principle of government by law, toward the newer doctrine of government by men. The purpose of renegotiation is to do away with "excessive profits," but no standard or formula has been fixed by the statute to determine what "excessive profits" are. That determination will be made by the men administering the law without statutory direction or help. I do not believe the price adjustment boards should in general consider any profit excessive unless there is something inordinate about it, something in excess of what the business might reasonably expect to earn in normal times. On the other hand, the price adjustment boards should not, and undoubtedly will not, renegotiate on a basis which will permit a contractor to retain a profit which has been greatly inflated by war contracts. But in any case the decision will depend largely on the judgment and wisdom of the men making it.

The Act authorizes a complete delegation of power. Procedure in the War Department illustrates just how this works out. The Secretary of 
War has delegated his authority to the Undersecretary of War. The Undersecretary of War has designated the War Department Price Adjustment Board as the coordinating agency of the War Department to determine and eliminate by renegotiation excessive profits from War Department contracts. To the services in the War Department (Ordnance Department, Quartermaster Corps, Corps of Engineers, Air Corps, etc.) is further delegated the actual business of renegotiation in the vast majority of cases. To enable them to perform their duty the services have set up local price adjustment sections in various parts of the country. Some of the sections operate independently; some are organized as administrative units of price adjustment boards, which have the responsibility locally of finally approving the renegotiation agreements. In Chicago, the Price Adjustment Section Board and the Price Adjustment Section of the Chicago Ordnance District will, in all likelihood, be concerned with renegotiating a major portion of the more than three billion dollars of government contracts which have been let in this district.

Procedure under the Act:-This is a new program, and experience may lead to many changes. The program has, however, progressed to a point where certain procedures have been established which seem to be appropriate for attaining the objectives sought. It may clarify these procedures to take one hypothetical case through from beginning to end of a renegotiation. Because I am familiar with the practice in the War Department, and particularly in the Ordnance Department, I shall use those departments for the purpose of illustration.

The case of the hypothetical contractor may come up for renegotiation in any one of several ways. In the first place, to remove contingent liabilities from its balance sheet, and to finish with the matter once and for all, and as soon as possible, the contractor may itself ask for renegotiation. This it can do either by communicating with the Chicago Ordnance District or with the War Department Price Adjustment Board. If the contractor does not act first, the Chicago Ordnance District may, on its own initiative, advise the War Department Price Adjustment Board that the contracts of this contractor should be renegotiated, or the War Department Price Adjustment Board may start the ball rolling without having had any prior official communication from any of the services or from the contractor. If the initiative is taken by one of the government agencies in any particular case, it may merely mean that this agency is anxious to get ahead with its work, or it may be due either to the fact that the contracts involved are relatively large or that the profits are believed to be particularly excessive. 
Whoever starts the machinery, the first step is to discover which of the four major departments is primarily interested. Does the Army, the Navy, the Maritime Commission, or the Treasury Department have the greater volume of contracts with the contractor? In this case we will assume that the War Department is chiefly interested. It is then the function of the War Department Price Adjustment Board to determine whether Ordnance, the Air Corps, the Engineer Corps, or any of the other services is chiefly concerned. Let us suppose that the contractor has sixty million dollars of contracts with the Chicago Ordnance District and forty million dollars of contracts with the Army Air Corps. On this assumption the contractor would be referred to the Price Adjustment Section Board of the Chicago Ordnance District for renegotiation. This board would renegotiate on an over-all basis all the contracts, those with the Air Corps as well as those with Ordnance. In doing so, however, it would to the extent practicable contact the Air Corps, so that, as nearly as possible, the results of the renegotiation would be satisfactory both to Ordnance and to the Air Corps. The contractor, however, would only be required to renegotiate once, and that, on the basis of the assumptions made, would be with the Price Adjustment Section Board of the Chicago Ordnance District.

When the case is received by the Ordnance District in Chicago for renegotiation, the very efficient Price Adjustment Section, which operates as the administrative unit of the Price Adjustment Section Board, goes immediately to work. The affairs of the contractor are studied from every possible standpoint. The officers of the company are contacted, and, among other things, are given the opportunity to present a statement justifying the profits which the contractor has made, or at least that part of those profits which they believe the contractor should be entitled to retain as not excessive. Statistical and business analyses are frequently made of the industry of which the contractor is a part, and are always made of the particular business of the contractor during the past years and during the current year. As already stated, war and commercial production are separated. Particular attention is given to its ratio of profits to sales before taxes in years preceding the war and in the year in which its war contracts are in effect. Increase in volume brought about by war contracts and the capital risks involved in the venture are carefully considered and weighed. Account is taken of the contribution to the war effort through the development of new processes, the manufacture of new articles of use to the military services, and the contribution to other manufacturers and the government of those procedures, ideas, and meth- 
ods which have been developed and been found useful in producing war material.

It should be said, to the credit of the American manufacturer and the capitalistic system under which he operates, and to the credit of freedom of individual enterprise on which that system is based, that many vital contributions of this kind have been made. It is now generally recognized that never in the history of the world has any nation approached the volume of production which is being attained by American industry today. It should also be recognized that the quality of this production is of the very highest.

No one test to determine the amount of excessive profits is conclusive, and none should be applied as a pure mathematical formula. Probably the most significant figure, for purposes of comparison, is the ratio of profits (before federal taxes) to sales in prewar years. For example, a company which has averaged I 5 per cent profit on sales in such years, on an average annual volume of twenty million dollars could not normally justify a 20 per cent profit on forty million dollars of war contracts. Whether the profit on such contracts should be reduced, in order to squeeze out the "excessive" portion, to I 5 per cent or Io per cent or some other percentage, will depend on many other factors, all of which must be carefully weighed. It is clear, too, that in those cases where not merely the product itself but the character of manufacturing has been materially changed by the war, a comparison of prewar profit ratios with wartime profit ratios may not be of any real significance.

It should be noted that the profits primarily (though not exclusively) considered are those before income and excess profits taxes. This must necessarily be true. Many companies, with no war business at all, are finding their profits after taxes much reduced. The war contractor cannot, and in general does not, expect exceptional treatment in this respect. This does not mean that no weight at all is given to the profits after taxes, but it is clear that if too much consideration were given to such profits it would in effect mean that the renegotiators were rewriting the tax law. Renegotiation must therefore deal mainly with profits before taxes and leave what remains to the gentle ministrations of the Bureau of Internal Revenue under the provisions of the income and excess profits tax laws. "Excessive" profits are one thing; "excess" profits, another.

After consideration has been given to all the factors involved, at a second or third, or perhaps even a fourth, meeting with the officers of the contractor, an agreement is reached as to the amount of the excessive profits in all its renegotiable contracts and subcontracts. This agreement, 
approved by the Price Adjustment Section Board of the Chicago Ordnance District, is then forwarded, through the office of the Chief of Ordnance, to the War Department Price Adjustment Board. That board should, I believe, review the agreement reached with two purposes primarily in mind. It should attempt, first, to avoid any gross errors or mistakes which may have occurred, and, second, to preserve a minimum of uniformity between the decisions reached in the various local boards and sections throughout the country. Absolute uniformity should not be sought, for it cannot be attained unless a formula is applied to the determination of excessive profits, and there is no formula. Necessarily much is left to the judgment of the men administering the Act. So long as that judgment is good, however, I submit that business is far better off than it would be if a fixed mathematical standard were arbitrarily applied to every case. There will be profits which, if the facts are all known, would be considered excessive by any reasonable man. There will be profits which, if the facts are all known, would not be deemed excessive by any reasonable man. There is a middle ground, however, within which reasonable men, knowing the facts, may differ. If an agreement fixes the profits within this middle ground, it is all that can be asked for in this field.

To return to our hypothetical case: When the agreement has been approved by the War Department Price Adjustment Board it goes to the Undersecretary of War for his signature, having already been signed by the contractor. The signature of the heads of the other interested departments, if any, will also be procured. This ends the renegotiation procedure.

How Excessive Profits Are Eliminated.-Several methods are described in the statute for eliminating excessive profits after the amount has been settled. This may be done either by a reduction in the contract price for the balance of the term of the contract, or by witholding from amounts otherwise due the contractor the amount of the excessive profits, or by recovery from the contractor of a cash refund, or by directing a contractor to withhold for the account of the United States payments which would otherwise be due to a subcontractor, or by any combination of these methods. Once the amount of the excessive profits has been agreed upon, the government will cooperate in every possible way to implement the agreement with the least disturbance to the business of the contractor. One factor that must be examined with care is the amount of working capital available to it. The contractor will not be expected to 
refund the excessive profits in cash if that depletes its current resources beyond the safety point.

Among the amendments to the law adopted as a rider to the Revenue Act of 1942 is one which provides that in determining the excessiveness of profits realized, the secretary shall recognize the properly applicable exclusions and deductions of the character which the contractor is allowed under the income and excess profits tax sections of the Internal Revenue Code. This means that in determining the amount of profits realized by it the contractor shall be allowed to deduct those costs which are of the same character as those which it would be allowed to deduct in determining whether or not it has a taxable income. This, however, is no guide to the amount' of the profits which is excessive.

Prior to the enactment of the amending statute, the effect of the payment by a contractor of an income and excess profits tax on the very profit, which by renegotiation might later be determined excessive, was extremely uncertain. The Treasury Department had sought to work out a fair adjustment by a ruling designated I.T. $3577 .^{3}$ This ruling is now supplemented by the new Section 3806 of the Internal Revenue Code. One of the principal objects of this Section is to give the contractor which renegotiates profits on which it has already paid a tax, credit for the amount of the tax paid. For example, if in April, 1943, it should be agreed that the excessive profits realized by a particular contractor in I942 on its government contracts was one million dollars, and this contractor had already paid eight hundred thousand dollars income and excess profits tax on these profits, it would only be required to refund to the government the difference between these two figures, or two hundred thousand dollars.

The procedure followed by the War Department in administering this Act has been briefly described. The other branches of the government work along similar lines, with some individual variations. At first, the Navy centralized its renegotiations in Washington. It is now in the process of decentralizing, and local boards are being set up somewhat as has already been done by the Army Ordnance Department. At this time, the writer is not advised as to what steps toward renegotiation are being taken by the Treasury Department, which was included in the price renegotiation program for the first time by the amendments of October 2I, I942. The Maritime Commission is, I believe, doing all of its renegotiation in Washington, through a board which sits there.

${ }_{3}^{3}$ C.C.H. Fed. Tax Serv. If 6,485 (r942). 
Objections to the Act.-This law is certainly not beyond criticism. Perhaps the most fundamental objection to it is that it tends to break down belief and faith in the inviolability of contracts. If the government has agreed with a contractor to pay it two thousand dollars for a tank, and the contractor performs in every detail, is it right that the government should later, after the tank has been produced, reduce its price to fifteen hundred dollars?

It would be tragic indeed if this law operated to discourage efficiency, as some of its critics have asserted it does. The argument is made that if all profits are taken from the contractor no incentive is left to lower costs and thus increase profits. There are two answers to this accusation. First, all profits are not taken from the contractor by renegotiation, but only those deemed to be excessive. Second, if the job of renegotiation is done as it should be, reduction in costs will be encouraged by allowing a higher ratio of profits to the low- than to the high-cost producer. A 2 per cent profit on sales might be excessive for the inefficient producer; to per cent might not be excessive for the competent producer.

Constitutionality:- To the extent that the renegotiation program is carried out by agreements made between the government and contractors, it would seem that no constitutional question can arise. If in any case it should be impossible to obtain an agreement, and the secretary, in the exercise of the power which the statute purports to grant, should, without the consent of the contractor, fix a new price and refuse thereafter to pay the contract price for weapons already manufactured and delivered, the matter might become involved in litigation which would squarely raise the constitutional point.

Are the war powers of the government sufficient to justify the abrogation of a government contract? Does the due process clause of the Fifth Amendment to the Constitution prohibit the Federal Government from violating a contract which it has made? In the so-called, and somewhat incomprehensible, "gold clause" cases, ${ }^{4}$ the Supreme Court held that the joint resolution of Congress prohibiting payment in gold, which the government bond required, was unconstitutional, deciding, however, at the same time that the bondholder did not suffer any damage as a result of the failure to pay in gold. The question will not be argued here, but the writer's guess is that the Supreme Court would find that the Renegotiation Statute, and action under it, are a valid exercise of the Federal Government's war powers.

4 Nortz v. United States, 294 U.S. 3 I 7 (r935); Perry v. United States, 294 U.S. 33 (I935). 
Merits of the Act.-The law has certain significant merits. Perhaps the greatest of these is that it permits contractors voluntarily to divest themselves of those profits believed to be excessive, and thus to protect all industry from dangerous criticism to which it might otherwise be subjected. The Honorable James F. Byrnes, Director of Economic Stabilization, is reported to have said in a recent address: "Twenty-four years ago we had another war. When our Army came home broke and jobless and learned how their neighbors had profited, they angrily demanded that it should never happen again. Every man in public life, regardless of political affiliation, pledged that we would take the profits out of war. It has not been done. Some day another Army will come marching home. There will be some without an arm, some without a leg, and many without a job. In that hour I pity the man who profited while these men suffered. If we would preserve private enterprise, if we would preserve the profit system, we must now take the profits out of war."

The war profiteer is not popular in this country. Public belief, whether justified or not, that business is profiteering in time of war, might well lead to retaliatory legislation of the most radical type. In the final analysis, therefore, this law may be of enormous advantage to industry, a defense against much more drastic action.

No normal American businessman wants to profit unduly in time of war. Most of those who are engaged in an all-out effort to produce weapons for our Army and Navy, are imbued with a deep patriotic spirit. Most of them are eager to do the best they can to bring this war to an early end. When they understand the real purpose of this Act and the service it can render to business itself, they generally cooperate with the renegotiation program to the best of their ability.

We are told that some seventy billion dollars of contracts have been let and many of these may be renegotiated. It is conceivable that the cost of the war effort may be reduced by several billions of dollars by means of the renegotiation program. If so, to that extent will the pressure of raising money by the sale of bonds and by taxes be reduced.

Renegotiation, too, will play some part, and perhaps not an insignifi. cant part, in the control of a dangerous and threatening inflation. We have price ceilings for articles sold to others than the United States Government. Supplementing the price ceilings, and in many cases in substitution for them, we have the control of costs and prices to the government through the renegotiation of its contracts.

Because the Act invokes a rule of men rather than of law, the character of the men administering it is of extreme importance. I believe that 
the country is particularly fortunate in having obtained the highest type of personnel for the price adjustment boards and sections which are carrying out these renegotiations throughout the country: I have had some contact with the War Department groups, and I have yet to meet a single member of any of those groups whose purpose is to use this Act as a means of reforming the world or bringing about a new economic system. These men believe in the preservation of a free society and free enterprise. They do not believe that a law which aims at "excessive" profits can possibly be interpreted to mean that all profits in time of war are excessive. On the contrary, they believe the language of the statute plainly implies that some profits are reasonable, and these men, in determining what is "excessive," will look at the problem not only from the standpoint of justice to the government, but also from the standpoint of justice to industry.

It may be that the care with which every case is being considered will so delay progress that it will be impossible within any reasonable period of time to complete the job for the thousands and thousands of contractors and subcontractors now included in the program. The remedy may be to raise the limit, so that no company shall be subject to renegotiation unless the total of its renegotiable contracts shall exceed five hundred thousand or one million dollars in amount. It may be that short cuts can be developed, particularly for the smaller organizations, which will save a great deal of time without any significant loss in accuracy. Something must be done to speed up the program, however, if it is to be completed by those now engaged in the task. Should renegotiation drag on for years there is a serious risk that it will fall into the hands of a bureaucracy which may consider that any profit is an excessive profit, and which may use the tremendous powers inherent in the program to bring about results not now contemplated.

There is one other possible change in the law which should appeal to all fair-minded persons. The Act now provides for renegotiation downward only. Price adjustment boards should be empowered to readjust prices upward as well as downward, so that any efficient and cooperative producer which had actually lost money or made a wholly inadequate profit on its war business might obtain an equitable adjustment. Renegotiation should not be a totally one-sided affair.

Much the greater part of all the War Department contracts have been let by the Ordnance Department. The country and the manufacturer are, therefore, both to be congratulated upon the character of men in that Departmént who are now directing renegotiations.' Col. Irving A. Duffy, 
on whom the primary responsibility for administrative procedure in that department falls, has shown a real appreciation of the problems involved and, through his own ability and the help of an able staff, is doing much to solve those problems.

The objectives of those who are at present administering this Act have been stated by Mr. Maurice $\mathrm{H}$. Karker, the very capable Chairman of the War Department Price Adjustment Board, to be, first, to stimulate and give incentive to the production of war materials and, second, to stimulate and give incentive for continuing reductions in cost and price. If administered with these objectives in view and so that the epithet "profiteer" can no longer be applied to American business, the Act, notwithstanding its difficulties and the fundamental questions which it raises, will prove to be of real value to the nation and to American industry. 